\title{
O ELDORADO BRASILEIRO
}

Expulsos de seu país pela pobreza, pelo desemprego e por tensões étnicas, os bolivianos que migram para o Brasil vêm em busca de prosperidade, mas desconhecem as duras condições de trabalho que encontrarão por aqui. Muitos acabarão vivendo em regime de semiescravidão

Que há um grande número de imigrantes ilegais bolivianos vivendo no Brasil, especialmente na cidade de São Paulo, é fato muito conhecido. Igualmente conhecidas são as precárias condições de vida que muitos desses imigrantes encontram no nosso país. Trabalhando em tecelagens e confecções dos bairros do Brás, Bom Retiro e Pari, eles são sujeitos a jornadas extenuantes, que variam de 16 a 20 horas diárias. Recebem remunerações ínfimas por peça produzida e em geral moram em condições indignas, na própria oficina. Já chegam ao emprego com dívidas, referentes à compra da passagem feita por um aliciador e até mesmo à própria máquina industrial de costura que será seu instrumento de trabalho. Vivem, em suma, em condições de semiescravidão, em plena São Paulo, mais de 120 anos após a abolição legal desse regime no Brasil. 


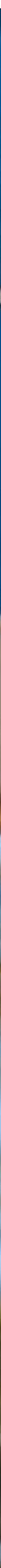


Uma faceta um pouco menos discutida desse fenômeno, no entanto, diz respeito às expectativas com que esses imigrantes vêm para cá. Expulsos de seu país pela pobreza, pelo desemprego e pela discriminação racial, a maioria empreende a viagem em busca de prosperidade, desconhecendo por completo as condições de vida que encontrarão por aqui. Contrastando com brasileiros que buscam melhores condições na Europa e nos Estados Unidos, para os bolivianos, o eldorado é aqui. A fim de compreender melhor essa situação, fomos conversar in loco com quem convive com essa realidade.

A FRONTEIRA. A cidade de Corumbá, no estado do Mato Grosso do Sul, é uma das principais portas de entrada desses imigrantes. Ali, o brasileiro João Hellensberger Filho coordena a Pastoral do Migrante, um serviço eclesial voltado a acolher e orientar os imigrantes recémchegados. Há anos em contato com esses trabalhadores, João descreve assim as expectativas com que eles se aventuram no Brasil: "Eles vêm atrás de uma nova vida, querem uma chance de crescer e de conseguir dinheiro. O Brasil é visto como uma galinha dos ovos de ouro".

Dirceu Rodrigues Moreira Júnior, agente do posto da Polícia Federal de Corumbá, descreve a situação com tons fortes: "Esse pessoal chega aqui desesperado, parece que estão fugindo da Bolívia", afirma. E a "fuga" a que se refere o agente federal não é, de fato, tão fantasiosa. A Bolívia tem cerca de $60 \%$ de sua população vivendo abaixo da linha de pobreza, perdendo apenas, na América do Sul, para o Suriname. Expulsos pelo desemprego e pela falta de perspectivas em seu país, esses trabalhadores buscam no Brasil uma alternativa.

Padre Tarcísio Criveller, que atua na Pastoral do
Migrante desde 2007, completa: "Eles vêm de uma situação muito difícil e, por isso, qualquer perspectiva é melhor do que ficar lá. Qualquer solução é melhor do que aquilo pelo que eles passam. Só que, na grande maioria, eles não sabem é que, por aqui, não vão encontrar solução nenhuma".

\section{Por mais dura que a vida seja em São Paulo, muitos desses trabalhadores conseguem enxergar melhores perspectivas aqui do que no país de origem}

SITUAÇÃO EM CASA. Junto à falta de emprego e perspectiva econômica, a discriminação por raça é outro fator de expulsão do país de origem. O período de 2003-2005 foi caracterizado pela instabilidade política e por um acirramento das tensões entre etnias. Na parte ocidental, onde está o altiplano andino, justamente a região mais miserável da Bolívia, concentram-se os collas, como são chamados os descendentes de índios, que correspondem a 55\% da população (30\% Quéchua e 25\% Aymará). Esses grupos vivem em área rurais e têm suas atividades ligadas à criação de animais e mineração; essa última, porém, encontra-se em crise devido ao esgotamento dos recursos que foram intensamente explorados ao longo da história.

Já na parte oriental, mais próspera e globalizada, vive uma população mestiça, conhecida como cambas, que corresponde a 30\% da população do país, além dos descendentes de europeus, que representam os 15\% restan- 
tes. Aqui se encontram as reservas bolivianas de gás natural e atua um grande número de empresas multinacionais, dinamizando a economia. O resultado é um clima de discriminação nas relações entre as partes. Justamente por conta da rivalidade étnica, os collas também sofrem com más condições de trabalho e até mesmo processos escravizadores dentro de seu próprio país.

A VIAGEM. Em contato diário com esses imigrantes desde 2002, Manoel Luis Neves Prestes, funcionário da empresa de ônibus Andorinha, define a expectativa desses que representam $50 \%$ da lotação dos ônibus com destino a São Paulo: "Os bolivianos que fazem essa viagem olham para o Brasil e acham que o país será uma porta de entrada para o trabalho".

Dono de dois pequenos comércios de roupas na cidade boliviana de Puerto Quijarro, na região fronteiriça, o boliviano Roberto Solares é um dos poucos com quem conversamos que mostram saber o que se passa nas oficinas de costura paulistanas: "Eu ouço falar que eles não têm acesso à rua, que ficam dentro de casa e não podem sair, com medo da polícia". Ainda assim, o comerciante expõe seu desejo de migrar em busca de alguma prosperidade: "Penso em algum dia, talvez, ir viver lá para trabalhar também, desde que não haja esses maus tratos".

É interessante ressaltar que muitos empregadores, bem como os aliciadores que organizam e financiam a viagem, costumam ser, eles próprios, bolivianos. Segundo o padre Tarcísio, essa prática de bolivianos enganarem e agenciarem conterrâneos é antiga: "É gente que conseguiu prosperar, ganhou experiência e consegue ganhar dinheiro em cima da pele dos outros: vendem a pessoa, vendem sonhos".
SÃO PAULO. Em uma praça na rua Pedro Vicente, entre os bairros paulistanos do Pari e do Canindé, com nome inspirado em uma flor típica de seu país - Kantuta parte da comunidade boliviana encontrou em uma feira semanal uma forma de confraternizar. Perguntamos a Javier, boliviano já com alguns anos em São Paulo, se ele sente saudades da pátria: "A nostalgia de voltar à Bolívia existe em cada um dos bolivianos, mas pessoalmente eu quero ficar aqui. Não penso em voltar mais".

\section{Na praça Kantuta, onde a comunidade se reúne, os imigrantes que chegam sem emprego são recrutados por oficinas de costura, que são as principais empregadoras}

Apesar das condições de vida precárias, das ameaças de deportação, da falta de documentos, da vida sem liberdade, muitos ainda preferem enfrentar a batalha no Brasil. Cada peça produzida em uma oficina de costura lhes rende uma quantia irrisória, e, se danificada, tem de ser paga pelos trabalhadores. Mas, como isca, encontram-se aos montes, na praça Kantuta, placas com os dizeres "Necessita-se de costureiros". Quando estivemos lá, uma delas acenava com uma nova esperança que dificilmente se materializará: "Pagamos bem".

THAÍS ALEIXO, jornalista, a_thais@hotmail.com 